\title{
KONSEP PENGEMBANGAN BINA PRESTASI MAN DALAM MENINGKATKAN MUTU PENDIDIKAN
}

\author{
Sri Winarsih \\ Pascasarjana IAINU Kebunen \\ Email : winasih2014@yahoo.co.id
}

\begin{abstract}
Abstraks
Konsep "Bina Prestasi" fo cused pada Siswa sebagai objek pendidikan, obyek hasil Study.the pendidikan dari sisi output, Proses dan kualitas input. The pendidikan dapat dilihat dari nilai bahwa produk dengan pendidikan, kuman mandi pendidikan and..or..that produk bisa melakukan dengan peningkatan program kualitas education. The dari sumber peningkatan of.human quality. by peningkatan kualitas pendidikan akan memberikan manfaat bagi the.. productivity, moral, kerja, stabilisasi, The flexsibility lembaga di mengantisipasi lingkungan tidak hanya di dalam tetapi juga di luar organisasi.
\end{abstract}

Kata kunci: Konsep, Bina Prestasi, Kualitas Pendidikan

\begin{abstract}
The Concept of "Bina Prestasi" fo cused on the Students as the object of education,object of Study. the result of education from the output side,proses and input.The quality of education could be seen from the value that product by education, germ education bath product and..or..that could do by the improvement of the quality education. The program of the improvement of human resources quality. by the improvement of education quality will give the benefit to the.. productivity, moral, work, stabilization, The flexsibility of institution on anticipating environment not only inside but also outside organization.
\end{abstract}

Keywords: Concept, Bina Prestasi,Quality Education

\section{PENDAHULUAN}

Undang-Undang Dasar 1945 pasal 31 (1) yang berbunyi ; Bahwa setiap warga negara berhak mendapatkan pendidikan. Oleh karena itu seluruh komponen bangsa yang mencakupi orang tua, masyarakat, dan pemerintah memiliki kewajiban dalam bertanggung jawab untuk mencerdaskan kehidupan 
bangsa melalui pendidikan. Pasal ini menerangkan Pengakuan (Equality dan Equity) terhadap hak asasi setiap individu anak bangsa untuk menuntut pendidikan yang secara mendasar telah mendapatkan pengakuan secara legal.

Mengenai tanggung jawab pemerintah terhadap Pendidikan secara tegas telah dicantumkan di dalam; Undang-Undang Dasar 1945 pasal 31 ayat (3) yang menyatakan : Bahwa pemerintah mengusahakan dan menyelenggarakan satu sistem pendidikan nasional yang meningkatkan keimanan dan ketakwaan serta akhlak mulia dalam rangka mencerdaskan kehidupan bangsa yang diatur dengan Undang-undang. Pasal ini juga menegaskan implementasi dari Pendidikan yang menggunakan Pendekatan Makro, sehingga tanggung jawab dan suatu kewajiban bagi pemerintah menyelenggarakan Pendidikan.

Terkait dengan pernyataan tersebut, sejak tanggal 08 Juli 2003 pemerintah telah mengesahkan Undang-Undang RI No. 20 Tahun 2003 tentang Sistem Pendidikan Nasional menggantikan Undang-Undang No. 2 Tahun 1989 yang dianggap sudah tidak memadai lagi. Pembaharuan Sistem Pendidikan Nasioanal dilakukan untuk memperbarui visi, misi, dan strategi pembangunan pendidikan nasional. Dalam Undang-Undang No. 20 Tahun 2003 tersebut secara tegas memperkuat tentang amanat Undang-Undang Dasar 1945 pasal 31 tentang pendidikan.

Pada UU Sidiknas diisyaratkan terbentuknya Standar Nasional Pendidikan atau lebih dikenal dengan Peraturan Pemerintah Nomor 19 Tahun 2005 tentang Standar Nasional Pendidikan (SNP), mulai sekarang setiap sekolah pada semua satuan, jenis dan jenjang pendidikan termasuk MAN harus memenuhi SNP tersebut. Salah satu upaya untuk mencapai SNP, setiap sekolah wajib membuat program kerja agar dapat unggul dan berprestasi, pada kesempatan ini penulis membuat suatu program yang disebut dengan "Bina Prestasi". Program ini dianggap adalah bagian dari program kerja jangka panjang yang terdapat pada Rencana Strategis MAN.

Program Pengembangan Bina Prestasi terletak pada isi, kedalaman, dan luasan atau cakupan program sesuai dengan kondisi MAN dan tuntutan masyarakat sekitarnya. Bagi sekolah (MAN) yang memiliki potensi lebih tinggi akan dapat mencapai SNP relatip lebih cepat. Demikian sebaliknya, bagi sekolah yang miskin potensi akan lebih lamban dalam mencapai SNP.

Standar Nasional Pendidikan yang harus dicapai oleh tiap sekolah tersebut meliputi standar kelulusan, kurikulum, proses, pendidikan dan tenaga kependidikan, sarana dan prasarana, pembiayaan, pengelolaan, dan penilaian pendidikan. Sangat dimungkinkan MAN memenuhi standar kelulusan tetapi fasilitasnya belum standar atau sebaliknya. MAN saat ini kondisinya kurang 
dalam standar fasilitas seperti ruang kelas, laboratorium, buku, dan sebagainya dan secara bertahap akan dipenuhi selama kurun waktu tertentu. Demikian juga kondisi guru dianggap belum memenuhi SNP. Begitu seterusnya pada aspek-aspek lainnya. Melalui konsep pengembangan "Bina Prestasi", MAN dimungkinkan dalam waktu yang akan datang (Secepatnya) mampu mencapai standar yang diinginkan. Dan apabila suatu MAN telah memenuhi Standar, maka diharapkan akan mampu menyelenggarakan pendidikan secara efektif, efisien, dan berkualitas.

Oleh karena itu Program Pengembangan "Bina Prestasi" ini dipandang sangat penting guna pencapaian standar yang mampu memberikan arah dan pegangan dalam rangka pencapaian tujuan tersebut.

Rencana Pengembangan Bina Prestasi diharapkan menjadi salah satu cara untuk mengatasi permasalahan yang ada, dalam proses penyelenggaraan pendidikan MAN dalam pencapaian tujuan yang diharapkan.

\section{PERMASALAHAN}

Ditinjau dari Undang Undang dasar dan UU Sisdiknas, Secara retorik ada dua tinjauan permasalahan pendidikan, yatiu secara makro dan mikro. Secara mikro kontens sudut pandang kita adalah Sekolah, dalam hal kaitan dengan objek permasalahan ini adalah MAN. Tuntutan reformasi di bidang pendidikan sudah lama ditunggu tunggu kalangan pendidikan di sekolah, yakni diberinya peluang bahkan dalam batas tertentu diberikan kebebasan, kepada sekolah (MAN) dan masyarakat untuk menyelenggarakan pendidikan sesuai dengan minat dan kebutuhan masyarakat serta sesuai dengan kondisi dan tuntuan lapangan. Hal ini berarti bahwa intervensi pemerintah yang berlebihan dalam penyelenggaraan pendidikan dikurangi atau setidaknya sekolah diberi wewenang penuh untuk berkreasi meningkatkan mutunya.

Permasalahan pendidikan yang sering disorot dan erat kaitannya dengan peningkatan mutu pendidikan adalah manajemen (pengelolaan) pendidikan. Dalam kontens Pendidikan pada tingkat Mikro, pada pola pelaksanaan pembelajaran dikelas perlu dilakukan perubahan. Konsep pengembangan pada "Bina Prestasi", memfokuskan peserta didik sebagai objek pendidikan, objek pembelajaran, mempertimbangkan hasil pendidikan dari sudut hasil (output), dan proses.

Dengan demikian permasalahan yang muncul dalam pendidikan secara mikro pada MAN, adalah ; "Belum terlaksananya optimalisasi potensi dan proses pendidikan yang berorientasi bagi peserta didik MAN dan masih ada beberapa Tenaga Pendidik yang ngajar tidak sesuai dengan Bidangnya sehingga sertifikasinya pun juga tidak sesuai dengan Bidangnya”. 
Maka perlu adanya suatu program penunjang guna peningkatan , mutu MAN, melalui kegiatan "Bina Prestasi, yang mengawali kegiatan peningkatan mutu dari internal MAN.

\section{PENDIDIKAN SEBAGA SEBUAH INVESTASI}

Konsep pendidikan sebagai sebuah investasi (education as investement) telah berkembang secara pesat dan semakin diyakini oleh setiap negara bahwa pembangunan sektor pendidikan merupakan prasyarat kunci bagi pertumbuhan sektor-sektor pembangunan lainnya. Konsep tentang investasi sumber daya manusia (human capital investment) yang dapat menunjang pertumbuhan ekonomi (economic growth), sebenarnya telah mulai dipikirkan sejak jaman Adam Smith (1776), Heinrich Von Thunen (1875) dan para teoritisi klasik lainya sebelum abad ke 19 yang menekankan pentingnya investasi keterampilan manusia.

Schultz (1960) kemudian memperhatikan bahwa pembangunan sektor pendidikan dengan manusia sebagai fokus intinya telah memberikan kontribusi langsung terhadap pertumbuhan ekonomi suatu negara, melalui peningkatan keterampilan dan kemampuan produksi dari tenaga kerja. Penemuan dan cara pandang ini telah mendorong ketertarikan sejumlah ahli untuk meneliti mengenai nilai ekonomi dari pendidikan.

Perkembangan tersebut telah mempengaruhi pola pemikiran berbagai pihak, termasuk pemerintah, perencana, lembaga-lembaga internasional, para peneliti dan pemikir modern lainnya, serta para pelaksana dalam pembangunan sektor pendidikan dan pengembangan SDM. Di negara-negara maju, pendidikan selain sebagai aspek konsumtif juga diyakini sebagai investasi modal manusia (human capital investement) dan menjadi "leading sektor" atau salah satu sektor utama. Oleh karena perhatian pemerintahnya terhadap pembangunan sektor ini sungguh-sungguh, misalnya komitmen politik anggaran sektor pendidikan tidak kalah dengan sektor lainnya, sehingga keberhasilan investasi pendidikan berkorelasi dengan kemajuan pembangunan makronya.

Kualitas pendidikan dapat dilihat dari nilai tambah yang dihasilkan oleh lembaga pendidikan, baik produk dan jasa maupun pelayanan yang mampu bersaing di lapangan kerja yang ada dan yang diperlukan. Peningkatan kualitas SDM dapat dilakukan melalui peningkatan kualitas pendidikan. Sehubungan dengan masalah ini, Nanang Fatah (2003:6) mengemukakan bahwa "Pendidikan sebagai suatu sistem yang dilihat secara mikro dan makro. Dari tinjauan makro maka peranan stakeholder akan memainkan perannya dan harus mengkaitkan sektor pendidikan dengan kebutuhan dunia kerja, artinya lulusan pendidikan 
semestinya memiliki kemampuan dan keterampilan yang relevan dengan tuntutan dunia kerja.

Program peningkatan kualitas SDM melalui peningkatan kualitas pendidikan akan memberikan manfaat pada lembaga berupa produktiitas, moral, efisiensi kerja, stabilitas, serta fleksibilitas lembaga dalam mengantisipasi lingkungan, baik dari dalam maupun ke luar lembaga.

MAN adalah salah satu sub sistem pendidikan, yang juga berperan dan bertanggung jawab terhadap peningkatan kualitas SDM melalui visi, misi dan tujuan pendidikan MAN yang diembannya. Oleh karena itu penulis merasa terpanggil untuk membuat suatu terobosan program peningkatan kualitas SDM, melalui peningkatan mutu MAN, dengan konsep pengembangan "Bina Prestasi”. Diharapkan konsep program ini dapat mengawali, mempercepat proses peningaktan Mutu MAN kedepan.

\section{PROGRAM PENGEMBANGAN BINA PRESTASI Pengertian Bina Prestasi}

Pengertian Bina Prestasi secara khusus bukanlah suatu definisi dari kajian ilmu atau defenisi sesuatu yang mengandung pengertian khusus, penulis hanya mengambil arti dari dua suku kata "Bina" dan "prestasi”, yang secara umum menyentuh suatu kegiatan pendidikan, dan bila dilihat dari arti generatif (Kamus Bahasa Indonesia) yaitu "bina" adalah membina, membangun, mengusahakan agar lebih baik, upaya untuk lebih maju, "Prestasi", adalah hasil baik yang dicapai. Dari arti kata diatas, penulis mengambil kesimpulan pengertian Bina Prestasi menjadi "upaya peningkatan mutu pendidikan MAN kearah yang lebih baik".

Pengertian dari Bina Prestasi diatas erat hubungannya dengan pengertian "Pendidikan", karena yang menjadi objek pembahasan adalah MAN sebagai institusi pendidikan. Oleh karena itu kita perlu mengetahui juga pengertian pendidikan itu sendiri.

Pengertian Pendidikan, secara umum adalah sesuatu yang mengandung arti "Suatu aktivitas untuk membantu pengembangan ilmu pengetahuan", Bila ditinjau dari kajian etimologi kata, Pendidikan sendiri berasal dari bahasa Inggris, yaitu Education yang juga berasal dari bahasa latin "Educare" yang berarti "memasukkan sesuatu". Dari kajian ilmu pendidikan, bahwa Ilmu Pendidikan disebut juga dengan sebutan "Pedagogics", dalam bahasa Inggris, yang diketahui berasal dari bahasa Yunani ; Dari kata "Pais" yang berarti anak, dan "Again" yang artinya membimbing, dari pengertian tersebut diatas dapat ditarik suatu pengertian bahwa Pendidikan adalah "Bimbingan yang diberikan pada anak". 
Banyak Pengertian tentang Pendidikan dibuat orang, berikut beberapa pandangan atau pengertian tersebut, antara lain:

a). Menurut Webster's New World Dictionary (1962) dalam Syaiful Sagala (2007:1) menyebutkan Pendidikan adalah "proses pelatihan dan pengembangan pengetahuan, keterampilan, pikiran, karakter, khususnya lewat sekolah formal".

b). Menurut Ahmad A.K Muda (2006: 134) Pedidikan adalah *kb. "Proses pengubahan sikap dan perilaku seseorang atau kelompok orang dalam usaha mendewasakan manusia melalui upaya pengajaran dan pelatihan".

c). Menurut UU Sisdiknas No.20 th 2003 Pendidikan adalah usaha sadar dan terencana untuk mewujudkan suasana belajar dan proses pembelajaran, agar anak didik secara aktif mengembangan potensi dirinya untuk memeiliki kekuatan spiritual keagamaan, pengendalian diri, kepribadian, kecerdasan, serta keterampilan.

Banyak juga ahli tidak memperdulikan defenisi atau pengertian Pendidikan atau Ilmu Pendidikan itu sendiri, mereka lebih menyoroti "Proses" Pendidikan serta manfaatnya bagi perkembangan dan perubahan individu. Ilmu Pendidikan bukanlah suatu ilmu yang berdiri sendiri, tetapi sesuatu praktek penerapan ilmu lain dalam pendidikan. Fenomena yang terjadi dalam Pendidikan adalah terjadinya proses pengarahan perkembangan peserta didik, terjadi interaksi antara peserta didik dengan pendidik.

\section{Program Pengembangan Bina Prestasi dan Target Yang Harus Dicapai}

Sesuai dengan Peraturan Pemerintah nomor 19 Tahun 2005 tentang Standar Nasional Pendidikan (SNP), setiap sekolah termasuk MAN harus memenuhi SNP. Oleh karena itu, aspek-aspek yang harus disusun dalam perencanaan pengembangan sekolah juga harus sesuai dengan tuntutan SNP tersebut yaitu 8 (delapan) standar nasional pendidikan: kompetensi lulusan, isi (kurikulum), proses, pendidik dan tenaga kependidikan, pengelolaan, prasarana dan sarana, pembiayaan, dan penilaian.

Dalam konsep pengembangan "Bina Prestasi" untuk menuju prospek MAN yang lebih maju, penulis mengemukakan saran dalam programnya mengacu dan berpedoman pada pengembangan MAN, sesuai dengan konsep Standar Nasional Pendidikan. Hal ini akan sejalan dengan legalitas Pendidikan di Indonesia yang mengikuti Undang-Undang dasar, dan Undang-undang Sistem Pendidikan Nasional. Dalam pembuatan program MAN hanya menyesuaikan dengan karakteristik MAN yang secara substansial memang berbeda dengan 
Sekolah umum. Secara lebih rinci aspek-aspek yang dapat dikembangkan berdasarkan Standar Nasional Pendidikan sehingga dalam penyelenggaraannya efisien dan relevan, berkualitas, dan memenuhi pemerataan pendidikan, antara lain adalah sebagai berikut:

\section{Pengembangan Standar Isi (Kurikulum)}

Aspek-aspek yang Dikembangkan dalam Program-program Bidang Standar Isi (Kurikulum), Program-program yang dapat dikembangkan dalam standar isi (kurikulum) ini antara lain:

1) Pengembangan kurikulum satuan pendidikan (dengan berbagai jenis muatan kurikulum sesuai dengan ketentuan SNP)

2) Penyusunan kalender pendidikan

3) Pengembangan pemetaan KBK untuk semua mata pelajaran

4) Pengembangan silabus untuk semua mata pelajaran

5) Pengembangan sistem penilaian untuk semua mata pelajaran

6) Pengembangan rencana pelaksanaan pembelajaran untuk semua mata pelajaran

7) Penyusunan beban belajar

Target yang harus dicapai dalam aspek ini antara lain ditunjukkan oleh indikator-indikator:

1) Terdokumentasikan kurikulum satuan pendidikan yang dijalankan sekolah $(\mathrm{KBK})$

2) Tersedianya perangkat pembelajaran secara lengkap (pemetaan, silabus, rencana pelaksanaan pembelajaran), baik untuk semua mata pelajaran maupun semua jenjang kelas

3) Terdokumentasikan kurikulum satuan pendidikan di sekolah yang bersangkutan

4) Dan terdapat peningkatan lain yang terkait dengan standar isi pendidikan.

\section{Pengembangan Standar Proses Pendidikan}

Program Pengembangan Standar Proses Pendidikan pada MAN dalam upaya-upaya menuju kepada standar proses pendidikan sebagaimana halnya ditentukan oleh SNP, maka bagi sekolah (MAN) diharapkan mengembangkan berbagai program dan kegiatan, diantaranya adalah:

1) Pengembangan dan inovasi-inovasi metode pengajaran pada semua mata pelajaran, khususnya penerapan metode atau strategi pembelajaran kontekstual atau CTL (Contextual Teaching and Learning) 
2) Pengembangan dan inovasi-inovasi bahan pembelajaran

3) Pengembangan dan inovasi-inovasi sumber pembelajaran

4) Pengembangan dan inovasi-inovasi model-model pengelolaan atau manajemen kelas

5) Pengembangan dan inovasi-inovasi media pembelajaran dan sebagainya.

Target yang harus dicapai dalam aspek ini antara lain ditunjukkan oleh indikator-indikator:

1) Semua mata pelajaran pada semua jenjang kelas telah dilaksanakan dengan menggunakan berbagai strategi pembelajaran, utamanya CTL

2) Terdapat peningkatan inovasi bahan pembelajaran, baik secara kualitas maupun kuantitas

3) Terdapat peningkatan inovasi sumber pembelajaran, baik secara kualitas maupun kuantitas

4) Terdapat peningkatan inovasi pengelolaan kelas/pengelolaan pembelajaran dan sebagainya

\section{Pengembangan Standar Kompetensi Lulusan}

Adapun beberapa program dan kegiatan yang dapat dikembangkan yang berkaitan dengan standar kompetensi lulusan pendidikan ini antara lain:

1) Pengembangan standar kelulusan atau GSA pada setiap tahunnya

2) Pengembangan standar pencapaian ketuntasan kompetensi pada tiap tahun atau semester

3) Pengembangan kejuaraan lomba-lomba bidang akademik

Langkah-langkahnya :

1) Menyeleksi input dengan selektif yang akan masuk MARU.

2) Mengadakan pengayaan dan try out semua mata pelajaran setelah selesai sekolah semua siswa wajib ikut dari kelas X - XII.

3) Pembentukan kelompok-kelompok belajar berdasarkan tempat tinggal.

4) Mengadakan evaluasi, dan bagi siswa yang berprestasi diberi suatu penghargaan.

5) Membudayakan gemar membaca kepada siswa.

6) Mengembangkan kejuaraan lomba - lomba bidang akademik.

7) Membuat kelas khusus (eksekutif/istimewa) yang difasilitasi dengan sarana yang lengkap (seperti: ruangan ber AC, ada komputer, fasilitas internet, OHP, dan lain-lain.) bagi siswa yang berprestasi dan sebagainya. 


\section{Pengembangan Penggalian prestasi Non Akademik.}

Langkah-langkahnya:

1) Wali kelas menyebar angket yang isinya tentang "Bakat apa yang dimiliki siswa tersebut."

2) Mengadakan pembinaan sesuai dengan bakat siswa dan tutornya harus relevan.

3) Mengadakan kejuaraan lomba-lomba bidang non akademik.

4) Memberikan penghargaan kepada tutor dan siswa yang berprestasi dalam bidang non akademik.

Target yang harus dicapai dalam aspek ini antara lain ditunjukkan oleh indikator-indikator:

1) Terdapat peningkatan gain score achievement (GSA) pada setiap semester atau tahun, terhadap pencapaian keutntasan kompetensi untuk semua mata pelajaran

2) Terdapat peningkatan rata-rata pencapaian gain score achievement (GSA) pada tahun terhadap mata pelajaran yang ujikan berdasarkan kepada standar kelulusan yang ditetapkan

3) Terdapat peningkatan prestasi non akademik tiap tahunnya

4) Terdapat peningkatan prestasi akademik tiap tahunnya

\section{Pengembangan Standar Pendidik dan Tenaga kependidikan}

Adapun program-program dan kegiatan-kegiatan yang dapat dikembangkan mengenai standar pendidik dan tenaga kependidikan ini antara lain:

1) Pengembangan atau peningkatan kompetensi pendidik aspek profesionalisme

2) Pengembangan atau peningkatan kompetensi pendidik aspek pedagogik

3) Pengembangan atau peningkatan kompetensi pendidik aspek sosial

4) Pengembangan atau peningkatan kompetensi pendidik aspek kepribadian

5) Pengembangan atau peningkatan kompetensi tenaga TU dan lainnya

6) Pengembangan atau peningkatan kompetensi kepala sekolah

7) Pelaksanaan monitoring dan evaluasi oleh kepala sekolah terhadap kinerja pendidik dan tenaga TU atau lainnya, dan

8) Peningkatan kuantitas tenaga pendidik dan tenaga kependidikan

Target yang harus dicapai dalam aspek ini antara lain ditunjukkan oleh indikator-indikator: 
1) Terdapat peningkatan jumlah tenaga pendidikan dan kependidikan sesuai kebutuhan sekolah

2) Terdapat peningkatan kompetensi pendidik dan tenaga kependidikan sesuai SNP

3) Terselenggaranya ME tiap tahun khususnya tentang kinerja sekolah

4) Terselenggaranya ME tiap tahun khususnya tentang kinerja pendidik

5) Terselenggaranya ME tiap tahun khususnya tentang kinerja kepala sekolah

6) Terselenggaranya supervisi klinis tiap tahun khususnya kepada pendidik, dan

\section{Pengembangan Standar Prasarana dan Sarana Pendidikan}

Adapun program-program dan kegiatan yang dapat dikembangkan mengenai standar prasarana dan sarana baik secara kuantitas maupun kualitas antara lain:

1) Peningkatan dan pengembangan serta inovasi-inovasi media pembelajaran untuk semua mata pelajaran

2) Peningkatan dan pengembangan serta inovasi-inovasi peralatan pembelajaran untuk semua mata pelajaran

3) Pengembangan prasarana (ruang, laboratorium, dll) pendidikan dan atau pembelajaran

4) Penciptaan atau pengembangan lingkungan belajar yang kondusif

5) Peningkatan dan pengembangan peralatan laboratorium komputer, IPA, Bahasa, dan laboratorium lainnya

6) Pengembangan jaringan internet, baik bagi peserta didik, pendidik maupun tenaga kependidikan

7) Pengembangan atau peningkatan peralatan/bahan perawatan sarana dan prasarana pendidikan, dan

8) Pengembangan peralatan dan inovasi-inovasi pusat-pusat sumber belajar.

Target yang harus dicapai dalam aspek ini antara lain ditunjukkan oleh indikator-indikator:

1) Terdapat peningkatan kuantitas dan kualitas media pembelajaran tiap mata pelajaran untuk semua jenjang kelas, selaras dengan strategi pembelajaran yang diterapkan (khususnya CTL)

2) Terdapat peningkatan kuantitas dan kualitas peralatan pembelajaran tiap mata pelajaran untuk semua jenjang kelas, selaras dengan strategi pembelajaran yang diterapkan (khususnya CTL)

3) Terdapat peningkatan kuantitas dan kualitas prasarana pendidikan dan atau pembelajaran 
4) Terdapat peningkatan kuantitas dan kualitas media dan peralatan pembelajaran praktik tiap mata pelajaran untuk semua jenjang kelas, selaras dengan strategi pembelajaran yang diterapkan (khususnya CTL)

5) Terpasangnya jaringan internet, baik dalam lab komputer peserta didik, guru maupun kepala sekolah

6) Terlaksananya perawatan prasarana, peralatan, dan media pembelajaran atau sekolah secara berkala, dan

7) Terdapat prasarana sumber-sumber belajar yang memadai (perpustakaan, pusat media pembelajaran audio visual).

\section{Pengembangan Standar Pengelolaan Pendidikan}

Adapun beberapa program dan kegiatan yang dapat dikembangkan atau ditingkatkan pada standar pengelolaan pendidikan antara lain:

1) Pengembangan atau pembuatan rencana pengembangan sekolah (RPS) tiap tahun, baik untuk jangka pendek, menengah maupun panjang

2) Pengembangan pendayagunaan SDM sekolah dengan cara membuat dan pembagian tugas-tugas secara jelas

3) Pengembangan struktur dan keorganisasian sekolah sesuai dengan kebutuhan sekolah

4) Melaksanakan pembelajaran secara efektif dan efisien

5) Mendukung pengembangan perangkat penilaian

6) Pengembangan dan melengkapi administrasi sekolah

7) Implementasi MBS mengenai kemandirian/otonomi, transparansi, akuntabilitas, partisipasi/kerjasama, fleksibilitas, dan kontinyuitas baik mengenai program, keuangan, hasil-hasil program serta lainnya oleh pihak manajemen sekolah.

8) Pelaksanaan monitoring dan evaluasi oleh sekolah tentang kinerja sekolah

9) Pelaksanaan supervisi klinis oleh kepala sekolah

10) Penggalangan partisipasi masyarakat (pemberdayaan komite sekolah)

11) Membuat jaringan informasi akademik di internal maupun eksternal sekolah (SIM)

12) Membuat atau menciptakan jaringan kerja yang efektif dan efisien baik secara vertikal dan horisontal

13) Implementasi model-model manajemen: POAC, PDCA, dan model lain yang pada dasarnya mengembangkan aspek-aspek manajemen untuk pengembangan standar-standar pendidikan

14) Mengembangkan Income Generating Activities atau unit-unit produksi/ usaha di sekolah maupun kerjasama dengan pihak lain untuk menggalang partisipasi masyarakat, dan 
15) Melaksanakan dan membuat pelaporan-pelaporan kepada berbagai pihak yang relevan, baik menyangkut bidang akademik, non akademik atau manajemen sekolah lainnya.

Target yang harus dicapai dalam aspek ini antara lain ditunjukkan oleh indikator-indikator:

1) Terdapat dokumen rencana pengembangan sekolah (RPS) tiap tahun, baik untuk jangka pendek, menengah maupun panjang

2) Terdapat dokumen pengembangan pendayagunaan SDM sekolah dengan cara membuat dan pembagian tugas-tugas secara jelas beserta pelaksanaannya

3) Terdapat struktur dan keorganisasian sekolah sesuai dengan kebutuhan sekolah beserta tupoksi dan pedoman-pedoman kerjanya

4) Terlaksananya pembelajaran secara efektif dan efisien dengan dibuktikan oleh prestasi yang dicapai dan pemanfaatan input pendidikan yang ada

5) Tersedianya kelengkapan administrasi sekolah sesuai dengan kebutuhan dan memenuhi standar e-goverment yang efisien dan efektif

6) Mengimplementasikan MBS dengan indikator pencapaian sekolah/ manajemen mampu: mandiri/otonom, transparan, akuntabel, melakukan partisipasi/kerjasama dengan masyarakat dan lainnya, program-program dan pengelolaan yang fleksibilitas, dan terdapat kontinyuitas baik mengenai program, keuangan, hasil-hasil program serta lainnya oleh pihak manajemen sekolah

7) Kepemimpinan kepala sekolah mampu melaksanakan ciri-ciri sebagai leader yang tangguh

8) Terselenggaranya penggalangan partisipasi masyarakat (pemberdayaan komite sekolah) secara optimal dalam berbagai bentuk/bidang

9) Terdapat jaringan informasi akademik di internal maupun eksternal sekolah (SIM)

10) Terciptanya jaringan kerja yang efektif dan efisien baik secara vertikal dan horisontal

11) Terdapat berbagai model pengembangan pengelolaan sekolah

12) Terdapat sistem pengelolaan dalam Income Generating Activities atau unit-unit produksi/usaha di sekolah maupun kerjasama dengan pihak lain untuk menggalang partisipasi masyarakat secara profesional, dan

13) Terdapat dokumen laporan kepada berbagai pihak yang relevan, baik menyangkut bidang akademik, non akademik atau manajemen sekolah lainnya. 


\section{Pengembangan Standar Pembiayaan Pendidikan}

Dalam upaya membantu memenuhi dan mencapai standar biaya pendidikan yang memadai, maka MAN dapat mengembangkan program atau kegiatan yang didasarkan atas musyawarah dan mufakat serta persetujuan dari stakeholder serta sesuai dengan koridor peraturan perundangan yang berlaku, seperti:

1) Pengembangan jalinan kerja dengan penyandang dana, baik donatur tetap maupun tidak tetap

2) Penggalangan dana dari berbagai sumber termasuk dari sponsor

3) Penciptaan usaha-usaha di sekolah atau di luar sekolah sebagai Income Generating Activities

4) Pendayagunaan potensi sekolah dan lingkungan yang menghasilkan keuntungan ekonomik

5) Menjalin kerjasama dengan alumni, khususnya untuk penggalangan dana pendidikan

Target yang harus dicapai dalam aspek ini antara lain ditunjukkan oleh indikator-indikator:

1) Terjalin kerjasama dengan penyandang dana, baik tetap maupun tidak tetap dan terdapat pemasukan dana

2) Tertdapat usaha nyata sekolah dalam hal IGA atau unit produksi sekolah (koperasi, toko, kantin, dll)

3) Terdapat jalinan kerjasama dengan alumni dalam penggalangan dana

\section{Pengembangan Standar Penilaian Pendidikan}

Oleh karena itu perlu mengembangkan, meningkatkan dan melaksanakan beberapa program dan kegiatan penilaian seperti :

1) Pengembangan perangkat model-model penilaian pembelajaran

2) Implementasi model evaluasi pembelajaran: ulangan harian, ulangan tengah semester, ulangan akhir semester, ulangan kenaikan kelas, dll

3) Pengembangan instrumen atau perangkat soal-soal untuk berbagai model evaluasi

4) Pengembangan pedoman-pedoman evaluasi sesuai dengan pedoman yang telah ditetapkan oleh pemerintah atau BSNP

5) Pengembangan lomba-lomba, uji coba, dan sejenisnya dalam upaya peningkatan standar nilai atau ketuntasan kompetensi

6) Menjalin kerjasama dengan pihak-pihak terkait untuk melaksanakan penilaian dalam rangka pengembangan perangkat penilaian sampai dengan analisa dan pelaporan hasil belajar peserta didik, dan 
7) Melaksanakan kerjasama dengan pihak lain untuk melaksanakan tes atau uji coba prestasi peserta didik secara periodik

8) Target yang harus dicapai dalam aspek ini antara lain ditunjukkan oleh indikator-indikator:

9) Terdapat perangkat penilaian berbagai ragam untuk semua mapel semua jenjang kelas/tingka

10) Terselenggara berbagai model evaluasi: ulangan harian, ulangan tengah semester, ulangan akhir semester, ulangan kenaikan kelas, dll

11) Terdapat dokumen pengembangan bank soal, dan

12) Terdapat berbagai macam lomba, uji coba, dan jenis lainnya untuk peningkatan prestasi peserta didik.

Selain itu MAN juga harus menciptakan tradisi berbahasa arab dan bahasa inggris,agar peserta didik memiliki rasa percaya diri dan keberanian dalam berbicara serta mengekspresikan rasa dan pikirannya melalui bahasa asing. gagasan menciptakan tradisi dan lingkungan bahasa asing dapat di lakukan langkah-langkah sebagai berikut:

1) Memberlakukan Proses kegiatan belajar Mengajar di kelas dengan bahasa asing sebagai Pendamping (mapel Agama dengan menggunakan bahasa arab dan mapel umum dengan menggunakan bahasa inggris), selain dengan bahasa Indonesia.

2) Panduan akademik atau peraturan-peraturan yang di MAN baik untuk tenaga pendidik maupun kependidikan dan peserta didik dengan menggunakan tiga bahasa (Arab,Inggris,Indonesia).

3) Mengadakan Workshop dan perlombaan penulisan karya ilmiah untuk tenaga pendidik dan kependidikan serta peserta didik dengan menggunakan bahasa Arab dan bahasa Inggris.

4) Membuat "taman bahasa" sehingga peserta didik memiliki daya tarik dan nyaman dalam mengekspresikan bahasa asing.

5) Menyelenggarakan kursus bahasa Arab dan bahasa Inggris untuk tenaga pendidik dan kependidikan serta peserta didik yang tutornya di ambil dari luar lembaga untuk melancarkan komunikasi dalam berbahasa asing di dalam lembaga (MAN), dan sebagainya.

Dari berbagai program pengembangan tersebut selanjutnya dibuat kerangka kerja atau kerangka program dan target yang diinginkan dengan berbagai strategi pelaksanaannya. Sebelum menyusun kerangka program ada baiknya dilakukan dahulu kegiatan analisis situasi dengan membuat matrik analisis kondisi saat ini dan kondisi yang diharapkan dari masing-masing aspek, 
dan dibuat strategi atau program solusi penyelesaiannya. Untuk optimalisasi seluruh aspek permasalahan, dapat dilakukan workshop atau rapat bagi setiap unsur MAN, dan stakeholdersnya.

Matriks Analisis Penyusunan Program Berdasarkan Standar Nasional Pendidikan

\begin{tabular}{|c|c|c|c|}
\hline NO. & $\begin{array}{l}\text { KONDISI } \\
\text { SAAT INI }\end{array}$ & $\begin{array}{c}\text { KONDISI } \\
\text { YANG DIHARAPKAN }\end{array}$ & $\begin{array}{c}\text { PROGRAM } \\
\text { BINA } \\
\text { PRESTASI }\end{array}$ \\
\hline 1 & $\begin{array}{l}\text { STANDAR ISI } \\
\text { (KURIKULUM) }\end{array}$ & STANDAR ISI (KURIKULUM) & \\
\hline 2 & KOMPETENSI LULUSAN & KOMPETENSI LULUSAN & \\
\hline 3 & PROSES & PROSES & \\
\hline 4 & $\begin{array}{l}\text { PENDIDIK DAN TENAGA } \\
\text { KEPENDIDIKAN }\end{array}$ & $\begin{array}{l}\text { PENDIDIK DAN TENAGA } \\
\text { KEPENDIDIKAN }\end{array}$ & \\
\hline 5 & PRASARANA DAN SARANA & PRASARANA DAN SARANA & \\
\hline 6 & PENGELOLAAN & PENGELOLAAN & \\
\hline 7 & PEMBIAYAAN & PEMBIAYAAN & \\
\hline 8 & PENILAIAN & PENILAIAN & \\
\hline
\end{tabular}

\section{Manajemen Mutu Pendidikan}

Mutu berkenaan dengan penilaian bagaimana suatu produk memenuhi kreteria,standar atau rujukan tertentu.Dalam dunia pendidikan,Standar ini menurut Depdiknas (2001:2) dapat dirumuskan melalui hasil belajar mata pelajaran skolastik yang dapat diukur secara kuantitatif,dan pengamatan yang bersifat kualitatif,khususnya untuk bidang-bidang sosial.Kesepakatan tentang konsep mutu dikembalikan pada rumusan acuan atau rujukan yang ada seperti kebijakan pendidikan,proses belajar mengajar,kurikulum,sarana prasarana,fasilitas pembelajaran dan tenaga kependidikan sesuai dengan pihak-pihak yang berkepentingan.Oleh karena itu diperlukan adanya TQM (Total Quality Manajemen).Dari sini TQM dipahami sebagai suatu pendekatan dalam menjalankan usaha yang mencoba untuk memaksimumkan daya saing organisasi melalui perbaikan terus menerus atas produk,Jasa,manusia,proses dan lingkungannya.Untuk tercapainya TQM maka yang diperlukan adalah:

1) Fokus pada pelanggan,baik pelanggan internal maupun eksternal.

2) Memiliki obsesi yang tinggi terhadap kualitas.

3) Menggunakan pendekatan ilmiah dalam pengambilan keputusan dan pemecahan masalah.

4) Memiliki komitmen jangka panjang.

5) Membutuhkan kerja sama tim (teamwork). 
6) Memperbaiki proses secara berkesinambungan.

7) Menyelenggarakan pendidikan dan pelatihan.

8) Memberikan kebebasan yang terkendali.

9) Memiliki kesatuan tujuan.

10) Adanya keterlibatan dan pemberdayaan karyawan.

Mohammad Ali (2007:346) mengemukakan bahwa: Praktek penyelenggaraan pendidikan dapat dikiyaskan dengan proses produksi dalam sebuah perusahaan (industri). Hanya saja, produk yang dihasilkan lembaga pendidikan dalam bentuk jasa. Oleh karena itu lembaga pendidikan dapat dikatakan sebagai perusahaan jasa.

Dari prespektif ini, mutu dan kualitas layanan (jasa) yang dihasilkan merupakan ukuran mutu sebuah lembaga pendidikan. Yaitu sejauh mana kepuasaan pelanggan terhadap jasa yang dihasilkan.

Pelanggan di sini adalah pelanggan internal, yaitu guru dan tenaga kependidikan lainnya, dan pelanggan eksternal yaitu peserta didik dan pihak-pihak terkait di luar lembaga pendidikan tersebut. Dengan demikian, Madrasah dikatakan bermutu apabila mampu memberi layanan sesuai atau bahkan melebihi harapan guru, karyawan, peserta didik, dan pihak-pihak lain yang terkait seperti orang tua, penyandang dana, pemerintah atau dunia kerja pengguna lulusan.

Untuk memberikan jaminan terhadap mutu,lembaga pendidikan harus mengetahui dengan pasti apa yang dibutuhkan oleh pelanggannya. Lembaga pendidikan hendaknya selalu berupaya" mensinergikan" berbagai komponen untuk melaksanakan manajemen mutu pendidikan yang dikelolanya agar dapat menjalankan tugas dan fungsi kependidikan. Untuk itu, kerjasama dengan semua komponen madrasah dalam manajemen harus menjadi prioritas.

Oleh karena itu,untuk meningkatkan mutu pendidikan dengan cara" school based management" yang di Indonesia dikenal dengan istilah Manajemen Berbasis Sekolah (MBS).

Hal ini merupakan salah satu bentuk pembaharuan pendidikan, yang memberikan kewenangan penuh kepada madrasah untuk menyelenggarakan pendidikan agar produk yang dihasilkan sesuai dengan kebutuhan pelanggan pendidikan. Madrasah dapat dikatakan berhasil jika mampu memberikan layanan sesuai harapan pelanggan.

Menurut Syaiful Sagala (2009:170) mengemukakan bahwa: Sekolah /Madrasah dapat di katakan bermutu apabila prestasi Sekolah/Madrasah khususnya prestasi peserta didik menunjukkan pencapaian yang tinggi dalam : 
1) Prestasi Akademik yaitu nilai rapor dan nilai kelulusan memenuhi standar yang ditentukan.

2) Memiliki nilai-nilai kejujuran,ketaqwaan,kesopanan dan mampu mengapreasi nilai-nilai budaya.

3) Memiliki Tanggung Jawab yang tinggi dan kemampuan yang diwujudkan dalam bentuk keterampilan sesuai dengan dasar ilmu yang diterimanya di sekolah.

Untuk menjamin terselenggaranya pendidikan sesuai dengan"standar mutu" diperlukan penilaian secara terus menerus dan berkesinambungan terhadap kelayakan dan kinerja yang dilakukan dalam rangka melakukan pebaikan dan peningkatan mutu Madrasah.

Dari paparan di atas, dapat ditarik kesimpulan bahwa untuk menjamin pelaksanaan standarisasi mutu dan kualitas pendidikan, manajemen mutu mempunyai peranan penting. Sebab, kegiatan dalam manajemen mutu bukan sekedar berupaya agar produk yang dihasilkan memenuhi standar mutu, tetapi lebih difokuskan pada bagaimana proses produksi bisa terlaksana dengan baik, sesuai dengan prosedur yang seharusnya dilakukan agar dapat menghasilkan produk yang memuaskan pelanggan, khususnya masyarakat pengguna jasa pendidikan.

Dengan demikian peningkatan mutu pendidikan bukanlah tugas yang ringan karena tidak hanya berkaitan dengan permasalahan teknis, tetapi mencakup berbagai persoalan yang sangat rumit dan kompleks, baik menyangkut perencanaan,pendanaan,maupun efisiensi dan efektivitas penyelenggaraan sistem di sekolah/Madrasah.kuncinya adalah di Manajemen.’Maju Mundurnya suatu lembaga,Mutu dan tidaknya suatu lembaga tergantung bagaimana Manajemen di dalam lembaga tersebut".

\section{KESIMPULAN}

1. Pendidikan merupakan suatu bentuk investasi nasional untuk meningkatkan kualitas sumber daya manusia yang dibutuhkan terutama dalam pertumbuhan ekonomi modern.

2. Investasi pendidikan diharapkan menghasilkan suatu peningkatan kesejahteraan dan kesempatan yang lebih luas dalam kehidupan nyata.

3. Program Pengembangan Bina Prestasi MARU.

a) Pengembangan standar isi (kurikulum).

b) Pengembangan standar proses Pendidikan.

c) Pengembangan standar kompetensi lulusan. 
d) Pengembangan standar pendidik dan tenaga kependidikan.

e) Pengembangan standar prasarana dan sarana pendidikan.

f) Pengembangan standar pengelolaan pendidikan.

g) Pengembangan standar pembiayaan pendidikan.

h) Pengembangan standar penilaian pendidikan.

4. Pengukuran Manfaat Pendidikan dan Hasil Biaya Pendidikan.

Hasil dan manfaat pendidikan dapat diukur dari produktivitas kerja. Peningkatan efisiensi, meningkatnya kesadaran sosial, dan secara nasional meningkatkan pendapatan dan akhirnya kesejahteraan.

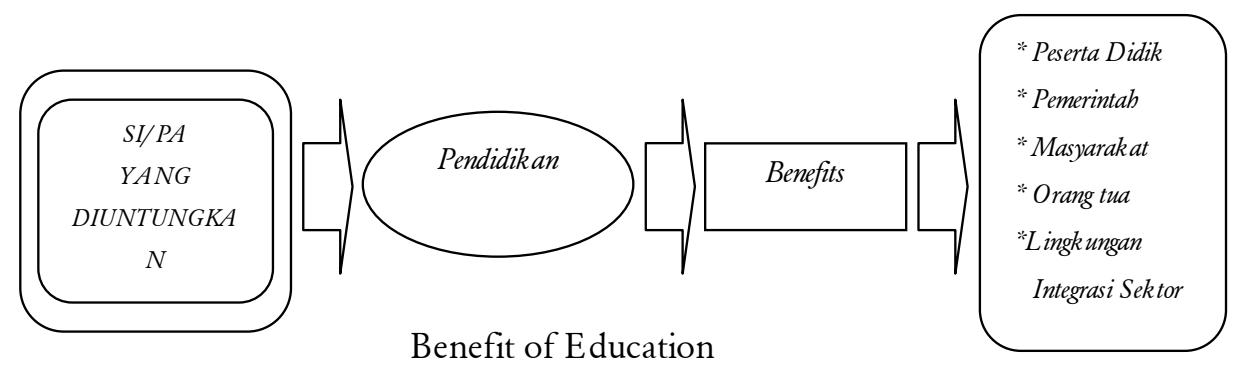

Measuring the benefit of education : pengukuran benefit adalah hasil akhir proses inouts - outputs of education

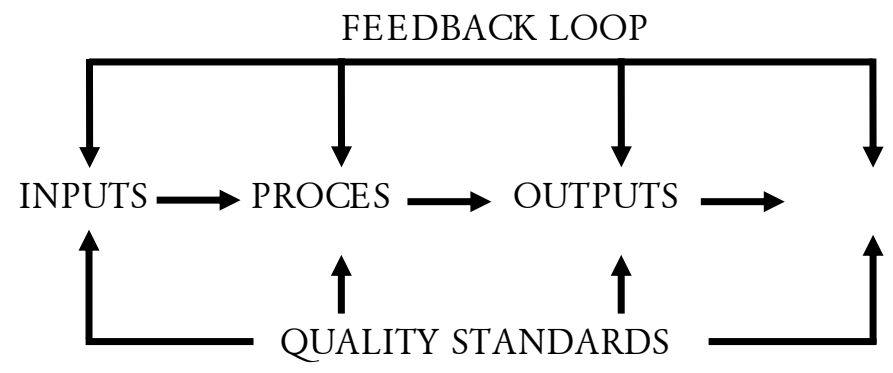

5. Manajemen mutu dimaksudkan untuk mencegah dan mengurangi resiko terjadinya kesalahan dalam proses produksi, dengan cara mengusahakan agar setiap langkah yang dilaksankan selama proses produksi dapat berjalan sesuai standar.

6. Upaya-upaya yang harus di lakukan untuk mengoptimalkan manajemen mutu adalah: mendongkrak prestasi,penghargaan dan hadiah,membangun tim,program akselerasi,mengimplementasikan kurikulum melalui budaya,melibatkan masyarakat, menghemat biaya pendidikan,dan membangun jiwa kewirausahaan,"Memanusiakan Manusia dan Menempatkan sesuatu pada Tempatnya,Serta menghargai SDM dan memberdayakannya" yang ada di MAN tersebut.

LITERASI, Volume V, No. 2 Desember 2014 $\mathrm{SI} / \mathrm{PA}$ 
7. Untuk menjamin pelaksanaan standarisasi mutu dan kualitas pendidikan, manajemen mutu mempunyai peranan penting. Sebab, kegiatan dalam manajemen mutu bukan sekedar berupaya agar produk yang dihasilkan memenuhi standar mutu, tetapi lebih difokuskan pada bagaimana proses produksi bisa terlaksana dengan baik, sesuai dengan prosedur yang seharusnya dilakukan agar dapat menghasilkan produk yang memuaskan pelanggan, khususnya masyarakat pengguna jasa pendidikan.

\section{DAFTAR PUSTAKA}

Aedi Nur, (2012), Dasar-dasar manajemen pendidikan,Bandung: CV.Pustaka Cendekia Utama.

Abdullah,Ishak, (2001), Filsafat ilmu pendidikan, Bandung: PT Remaja Rosdakarya.

Afzalur Rahman, (1991), Nabi Muhammad Sebagai Seorang Pemimpin Militer, Jakarta: Bumi Aksara

Depdiknas,(2003),Sistem Pendidikan Nasional

Edward Sallis, (2006), Total Quality Management in Education; Manajemen

Mutu Pendidikan (alih bahasa: Dr. Ahmad Ali Riyadi dan Fahrurrozi,

M.Ag.), Jogjakarta: IRCiSoD

E.Mulyasa,(2013),Pengembangan dan implementasi kurikulum 2013,Bandung:

PT.Remaja Rosdakarya.

E. Mulyasa, (2002), Manajemen Berbasis Sekolah Konsep Strategi dan Implementasi, Bandung: PT. Remaja Rosdakarya

Fattah, Nanang, (2003),Konsep Manajemen Berbasis Sekolah (MBS) dan

Dewan Sekolah.Bandung: Pustaka Bani quraisy.

Fandi Ciptono dan Anastasia Diana,(1998), Total Quality Management, Yogyakarta: Penerbit Andi.

Fandy Tjiptono dan Anastasia Diana,(2001), Total Quality Management,Yogyakarta: Penerbit Andi.

George Terry, (2003), Prinsip-Prinsip Manajemen (alih bahasa J. Smith D. F.M.), Jakarta: Bumi Aksara

Imam Munawwir Ek., tt., Asas-asas Kepemimpinan Dalam Islam, Surabaya:

Usaha Nasional

Imron Arifin, (1998), Kepemimpinan Kepala Sekolah dalam Mengelola Madrasah Ibtidaiyah dan Sekolah Dasar Berprestasi, Disertasi Doktor, Tidak dipublikasikan., Malang: IKIP Malang 
Inu Kencana Syafi'i, (2000), Al Qur'an dan Ilmu Administrasi, Jakarta: Bumi Aksara

Irham Fahmi,(2011), Manajemen (Teori,Kasus,dan Solusi), Bandung:Alfabeta. Jac Fitz-enz,(2000),The Roi Of Human Capital.

Lukman Saksono, (1992), Filsafat Kepemimpinan Studi Komparatif US Army, ABRI, dan Islam, Jakarta: Grafikatama Jaya

P. Sondang Siagian, (2003), Filsafat Administrasi Edisi Revisi, Jakarta: Bumi Aksara.

Pep Pard,Joe,Row Land,Philips,(1995).The Essence of Business Process re Enginering,Prentice Hall International (UK) Limited.London.

Melayu,S.P. Hasibuan, (2009), Manajemen Sumber Daya Manusia, Jakarta: Bumi Aksara.

Made Pidarta, (1988), Manajemen Pendidikan Indonesia, Jakarta: Bumi Aksara M. Dawam Rahardjo, (1995), Dunia Pesantren dalam Peta Pembaharuan dalam (Pesantren dan Pembaharuan), cet.ke-5., Jakarta: LP3ES

Mochtar Effendy, Ek., (1986), Manajemen Suatu Pendekatan Berdasarkan Ajaran Islam, Jakarta: Bhratara Karya Aksara

Moedjiarto, (2002), Sekolah Unggul Metodologi Untuk Meningkatkan Mutu Pendidikan, tanpa kota: Duta Graha Pustaka

Mohammad Ali, (2007), Guru dalam Proses Belajar Mengajar, (Bandung: Sinar Baru Algesindo

Muhammad Abdullah Al Buraey, (1986), Islam Landasan Alternatif Administrasi Pembangunan, Jakarta: CV. Rajawali

-, (1990), Management \& Administration in Islam, Dahran Saudi Arabia: King Fahd University of Petroleum \& Mineral.

Syaiful Sagala, (2009), Manajemen Strategik dalam peningkatan Mutu Pendidikan,Bandung: CV Alfabeta.

Peraturan Pemerintah Republik Indonesia Nomor 32 Tahun 2013, Tentang Perubahan atas Peraturan pemerintah Nomor 19 Tahun 2005 Tentang Standar Nasional Pendidikan.

Peraturan Pemerintah No.19 Tahun 2005 Tentang Standar Nasional Pendidikan (SNP). 